\title{
Contrasting timescales of crystallization and magma storage beneath the Aleutian Island arc
}

\author{
Brian R. Jicha*, Brad S. Singer, Brian L. Beard, Clark M. Johnson \\ Department of Geology and Geophysics, University of Wisconsin-Madison, 1215 West Dayton Street, Madison WI 53706, USA
}

Received 26 January 2005; received in revised form 2 May 2005; accepted 9 May 2005

Available online 23 June 2005

Editor: K. Farley

\begin{abstract}
Geologic, chronologic, and U-Th isotope data from Pleistocene-Recent basaltic to rhyolitic lavas and their phenocrysts constrain the long-term evolution of magmatic processes at Seguam Island, Aleutian Island arc, and suggest a model in which erupted magmas were derived from a single, deep seated reservoir for $\sim 130$ kyrs of its eruptive history. The monotonic evolution in $\left({ }^{230} \mathrm{Th} /{ }^{232} \mathrm{Th}\right)_{0}$ ratios is consistent with radiogenic ingrowth of ${ }^{230} \mathrm{Th}$ in a long-lived magma reservoir between 142 and $9 \mathrm{ka}$. Internal U-Th mineral isochrons from seven lavas and one ignimbrite are indistinguishable from their eruption ages as constrained by ${ }^{40} \mathrm{Ar} /{ }^{39} \mathrm{Ar}$ dating, which implies a short period (i.e., $10^{3}$ yrs or less) of crystal residence in the magma prior to eruption. These results can be reconciled if small batches of magma are repeatedly extracted from a deep, thermally buffered, basaltic reservoir, followed by decompression-driven crystallization and differentiation in small chambers or conduits in the upper crust immediately prior to eruption. Stratovolcano collapse at 9 ka produced a $4 \mathrm{~km}$ diameter caldera and a $70 \mathrm{~m}$ thick dacitic ignimbrite covering $\sim 12 \mathrm{~km}^{2}$. The ignimbrite, as well as subsequent rhyolitic and basaltic lava flows, signal a decrease in $\left({ }^{230} \mathrm{Th} /{ }^{232} \mathrm{Th}\right)_{0}$ and ${ }^{87} \mathrm{Sr} /{ }^{86} \mathrm{Sr}$ ratios. The abrupt change in magma composition at 9 ka most likely reflects disruption of the long-lived reservoir by rapid ascent of basaltic magma with low $\left({ }^{230} \mathrm{Th} /{ }^{232} \mathrm{Th}\right)$ and ${ }^{87} \mathrm{Sr} /{ }^{86} \mathrm{Sr}$ ratios and excess ${ }^{226} \mathrm{Ra}$. While the physiochemical connection between cone collapse and rise of new magma into the shallow crust remains to be explored, the shift in isotopic composition and evidence for a protracted $>100 \mathrm{kyr}$ period of magma storage, would have been missed had the focus been on only the most recent historical eruptions. Our results suggest that: not all arc basalt produced in the mantle wedge separates and ascends rapidly, magma ascent rates and storage times may vary significantly over periods of $10^{4}$ to $10^{5}$ yrs at a single arc volcano, and U-Th isotopes offer a means of better understanding relationships between explosive eruptions and changes in magma reservoir dynamics in island arcs, provided a sufficiently long period of volcanic activity is examined. (C) 2005 Elsevier B.V. All rights reserved.
\end{abstract}

Keywords: Aleutian island arc; U-Th isotopes; ${ }^{40} \mathrm{Ar} /{ }^{39} \mathrm{Ar}$ dating; magma residence; crystallization

\footnotetext{
* Corresponding author. Tel.: +1 608262 8960; fax: +1 6082620693.

E-mail address: bjicha@geology.wisc.edu (B.R. Jicha).
} 


\section{Introduction}

The rate at which magma ascends and the duration of storage, cooling, and crystallization govern the extent of chemical and volatile evolution, mechanisms of emplacement, and its occasional eruption at active arc volcanoes. In turn, appreciating the tempo of volcano construction, and how and when magmatic processes promote an explosive eruption or edifice collapse is one part of better predicting hazards that are concentrated in subduction zones. The evidence concerning kinetics of arc magmatic processes is sparse, mostly gleaned from but a few volcanoes, and has led to considerable controversy over ascent rates and crustal storage and differentiation times that typify subduction zones [1]. A central question is whether basaltic melt, once liberated at $\sim 75 \mathrm{~km}$ depth, ascends, crystallizes, differentiates, and erupts rapidly, within on the order of $10^{3} \mathrm{yr}$, thereby rising at $\sim 10^{2} \mathrm{~m} / \mathrm{yr}$ [2-4], or alternatively, if it is plausible that a significant volume of ascending magma stalls in the crust, where it may reside undisturbed, or differentiate for perhaps $>10^{5}$ yr prior to erupting [5,6].

Timescales of magmatic processes have been addressed using: crystal size distributions [7], major and trace element diffusion profiles in phenocrysts [8$10]$, and correlation between short-lived U-series isotopes and indices of differentiation [11]. The vast majority of U-series data are either from historical lavas, or large individual caldera-forming eruptions, thereby concentrating on a relatively narrow slice of time. This is because little time has elapsed since eruption thereby obviating a correction for in situ ${ }^{230} \mathrm{Th}$ ingrowth. However, a suite of young lavas and ash may fail to capture the full extent of erupted compositions, magmatic processes and growth rates that characterize large arc volcanoes. Where geochronologic control is good, it is clear that monotonic chemical evolution is rare, and that many abrupt or gradual shifts in composition, processes (e.g., crystallization vs. mixing vs. assimilation), and growth rate are expected to occur over periods of $10^{4}$ to $10^{5} \mathrm{yrs}$ at arc volcanoes (e.g., Mt Adams, [12]; Tatara San Pedro, [13]; and Seguam, [14]). Variations of Th isotope composition over these relatively long time periods offer a potentially powerful means of distinguishing shifts between open-and closed-system magmatic processes and constraining changes in magma ascent and crystallization rates [6,15-17]. The paucity of U-series data spanning the last several hundred thousand years mainly reflects the difficulty in establishing a precise chronology for latest Pleistocene to Holocene lavas [11]. Merits of this approach are illustrated at Mt. Etna, a large intraplate volcano, where variations in $\left({ }^{230} \mathrm{Th} /{ }^{232} \mathrm{Th}\right)_{0}$ ratios of lavas erupted over the last 200 kyrs have been attributed to periodic mixing of tholeiitic magma, characterized by low $\left({ }^{230} \mathrm{Th} /{ }^{232} \mathrm{Th}\right)_{0}$ ratios, with a deep, alkali basalt reservoir that has existed for at least the last 200 kyrs [15]. Remarkably, the timing of three distinct mixing events coincide with the three major caldera collapses at Etna, each signaling an abrupt change in the subvolcanic plumbing system [15].

The only study of a subduction zone volcano comparable to that of Etna was done 30 years ago on Irazu volcano, Costa Rica [6]. Mineral-glass UTh internal isochrons from five lavas at Irazu span $>100$ kyrs and show a progressive increase in $\left({ }^{230} \mathrm{Th} /{ }^{232} \mathrm{Th}\right)_{0}$ ratios that was inferred to reflect 140 kyrs of relatively undisturbed ingrowth of ${ }^{230} \mathrm{Th}$ in a crustal reservoir [6]. A few young, 0-4 $\mathrm{ka}$, island arc lavas and their phenocrysts have yielded U-Th isochrons with crystallization ages ranging from several that are indistinguishable from their eruption ages [18], to a few as much as 77 kyrs older than the eruptive age [19]. The older U-Th isochrons were initially interpreted to reflect long storage times for evolved and partly crystallized magma in crustal reservoirs [19], however, discrepancies between the U-Th isochron ages and those determined from ${ }^{226} \mathrm{Ra}-{ }^{230} \mathrm{Th}$ disequilibria and $\mathrm{Sr}$ diffusion profiles in plagioclase phenocrysts, suggest that there has been some mixing between magmas and cumulate crystals [10,20]. Moreover, ${ }^{226} \mathrm{Ra}-{ }^{230} \mathrm{Th}$ disequilibria in some whole rock samples constitute one of the more vivid arguments that arc magma ascends rapidly, i.e., within 5 half-lives of ${ }^{226} \mathrm{Ra}$ or $<8$ kyrs [2-4]. However, incomplete knowledge about the degree of ${ }^{226} \mathrm{Ra}^{230}{ }^{230}$ disequilibrium that persists in sub-arc mantle or crustal rocks comprising small amounts of hydrous minerals including phlogopite, has led to controversy [2123]. Rapid diffusion of ${ }^{226} \mathrm{Ra}$ from these minerals, if confirmed, would relax the constraint that magma must ascend rapidly and experience minimal storage times in hydrous, subduction-zone settings [21]. 
Advances in both the measurement of Th isotopes in small samples [24] and precise dating of late Pleistocene lava flows [25], prompted us to address the debate over rates of magmatic processes and explore temporal relationships between magmatism and volcanism over an extended, $\sim 150 \mathrm{kyr}$ period, in an otherwise well-characterized oceanic island arc setting. Here we present U-Th isotope data and ${ }^{40} \mathrm{Ar} /{ }^{39} \mathrm{Ar}$ age determinations from a basalt-rhyolite volcanic complex in the central Aleutian Island arc that provide evidence for vastly different timescales of crystallization and magma residence in a single crustal plumbing system.

\section{Geological setting and sample selection}

Seguam Island is a $200 \mathrm{~km}^{2}$ volcanic complex in the central Aleutian Island arc that comprises Pleistocene-Recent tholeiitic lavas and tephras (Fig. 1) [14]. Seguam was chosen for this study for the following reasons: 1) Compositions span a continuous range from 50 to 71 wt. $\% \mathrm{SiO}_{2}$, with an unusually large proportion, about $30 \%$, of the island comprising evolved dacitic and rhyolitic compositions [14], 2) the petrologic, geochemical, radiogenic $(\mathrm{Sr}-\mathrm{Nd}-\mathrm{Hf}-$ $\mathrm{Pb}$ ) isotope and $\mathrm{O}$ isotope characteristics of the erupted products are well-known $[14,26-28], 3)$ the entire eruptive history of the island has been mapped and is now exceptionally well-documented [29], 4) models of surface deformation based on pre-, syn-, and posteruptive magma and fluid migration through an upper crustal plumbing system have been developed from 10 years of interferometric synthetic aperture radar (InSAR) imagery [30,31], 5) geochemical data indicate that Seguam lavas reflect greater fluid and U-enrichments than other Aleutian volcanoes [32,33], and 6) the crustal structure is known from nearby seismic reflection and refraction profiles which indicate that the volcanic complex sits atop $25-30 \mathrm{~km}$ of arc crust [34]. An overall mafic composition for the crust, which comprises: porous or fractured extrusive and intrusive igneous rocks and volcaniclastic sediments in the upper $7 \mathrm{~km}$, a MORB-like layer in the middle

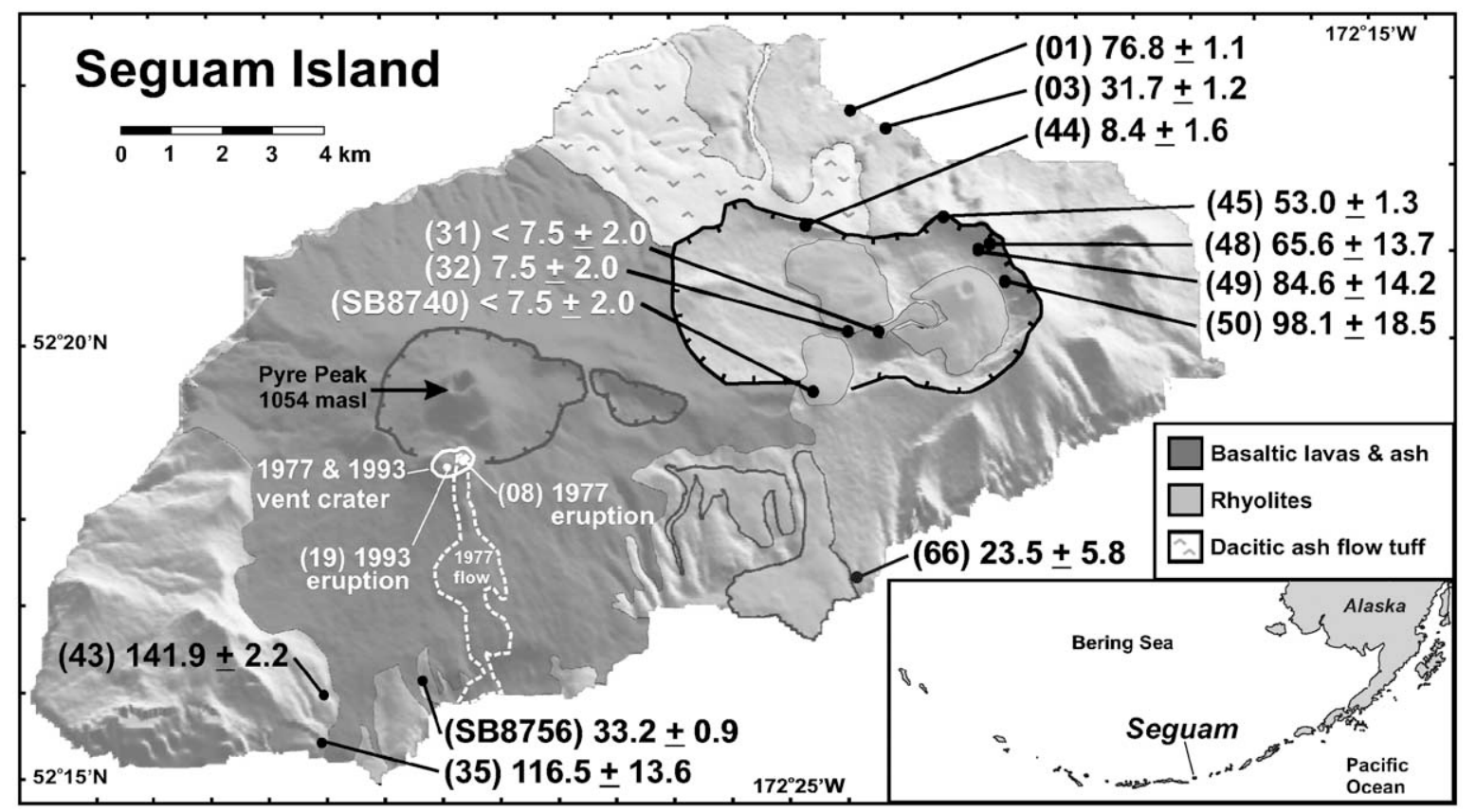

Fig. 1. Digital elevation model (DEM) of Seguam Island showing the locations of the SEG-03 samples (in parentheses), their eruptive ages and $\pm 2 \sigma$ uncertainties in ka. Hachured lines indicate caldera margins. White patterned area represents dacitic ignimbrite associated with caldera collapse at $\sim 9 \mathrm{ka}$. Gray and black shaded areas represent post-collapse rhyolitic and basaltic activity, respectively. White dashed line outlines the 1977 basalt flow. 
crust, and $\sim 19 \mathrm{~km}$ of gabbroic residua at the base, is inferred from the P-wave velocity structures [34].

Mapping, stratigraphy, and sixty ${ }^{40} \mathrm{Ar} /{ }^{39} \mathrm{Ar}$ age determinations indicate a 320 kyr history of subaerial volcanism on Seguam Island [[29]; unpublished data]. This study focuses only on the eruptive history from $142 \mathrm{ka}$ to present, which includes: 1) rhyodacitic dome formation at $142 \mathrm{ka} ; 2$ ) basaltic-rhyolitic cone building from 100 to $9 \mathrm{ka} ; 3$ ) collapse of a stratocone on the eastern half of the island and caldera formation at $\sim 9 \mathrm{ka}$, accompanied by emplacement of a dacitic ignimbrite, 4) resurgent rhyolitic dome growth in the eastern caldera, and 5) subsequent formation of a western caldera accompanied by mafic tuffs and basaltic effusions from within this caldera (Fig. 1, Table 1). Whole rock $\mathrm{Sr}$ isotope and $\delta^{18} \mathrm{O}_{\text {plag }}$ data from Seguam lavas combined with a comparison of the modal mineralogy to published low pressure cotectics suggest that basaltic parental magmas crystallized at 3-5 kb, or about $10-15 \mathrm{~km}$ depth, followed by closed-system differentiation to dacite and rhyolite between $1-2 \mathrm{~kb}$ (i.e., crustal depths of $\sim 3-6 \mathrm{~km}$ ) $[14,28]$.

Two of the basaltic lavas studied erupted in 1977 and 1993 A.D.; the eruptive ages of twelve additional lavas are known precisely from ${ }^{40} \mathrm{Ar} /{ }^{39} \mathrm{Ar}$ geochronology. The ages of two late Holocene rhyolitic domes are not known precisely, but on the basis of their surface morphologies, degree of weathering, and inferred stratigraphic positions, we are confident that they erupted after the rhyolite dome that we have ${ }^{40} \mathrm{Ar} /{ }^{39} \mathrm{Ar}$ dated at $7.5 \pm 2.0 \mathrm{ka}$ (Fig. 1, Table 1).

\section{Analytical methods}

\section{1. ${ }^{40} \mathrm{Ar}{ }^{39} \mathrm{Ar}$ geochronology}

Holocrystalline groundmass separates were prepared from porphyritic lava samples by crushing, sieving to $250-500 \mu \mathrm{m}$, magnetic sorting, and hand picking under a binocular microscope to remove olivine, pyroxene, and plagioclase phenocrysts and minimize the potential for xenocrystic contamination. Whole rock mini-cores, $5 \mathrm{~mm}$ in diameter ranging from $200-450 \mathrm{mg}$, were drilled from nearly aphyric lava flows. Groundmass separates ( 200-300 mg) were wrapped in $99.99 \%$ copper foil packets and, along with the mini-cores, were placed into $\mathrm{Al}$ disks with 1.194 Ma sanidine from the Alder Creek rhyolite as a neutron fluence monitor. The $\mathrm{Al}$ disks were irradiated for 20-90 min at the Oregon State University Triga reactor in the Cadmium-Lined In-Core Irradiation Tube (CLICIT) where they received fast

Table 1

Summary of ${ }^{40} \mathrm{Ar} /{ }^{39} \mathrm{Ar}$ incremental heating experiments

\begin{tabular}{|c|c|c|c|c|c|c|c|c|c|c|}
\hline \multirow[t]{2}{*}{ Sample } & \multirow[t]{2}{*}{ Description } & \multirow{2}{*}{\multicolumn{3}{|c|}{$\begin{array}{l}\text { \# Total fusion } \mathrm{N}^{\mathrm{a}} \\
\text { age } \\
\quad(\mathrm{ka} \pm 2 \sigma)\end{array}$}} & \multicolumn{3}{|c|}{ Isochron analysis } & \multicolumn{3}{|c|}{ Age spectrum } \\
\hline & & & & & $\begin{array}{l}\frac{40}{} \mathrm{Ar} \\
{ }^{36} \mathrm{Ar} \\
( \pm 2 \sigma)\end{array}$ & $\begin{array}{l}\text { Age } \\
(\mathrm{ka} \pm 2 \sigma)\end{array}$ & MSWD & $\begin{array}{l}\text { Increments } \\
\left({ }^{\circ} \mathrm{C}\right)\end{array}$ & $\begin{array}{l}{ }^{39} \mathrm{Ar} \\
\left(\%{ }^{\mathrm{b}}\right)\end{array}$ & $\begin{array}{l}\text { Plateau age } \\
\left(\mathrm{ka}^{\mathrm{c}} \pm 2 \sigma\right)\end{array}$ \\
\hline SEG $0332 \mathrm{gm}$ & Rhyolite dome & 3 & $8.4 \pm 3.2$ & 15 of 16 & $296.5 \pm 2.4$ & $6.1 \pm 3.5$ & 0.05 & $725-1450$ & 99.80 .04 & $7.5 \pm 2.0$ \\
\hline SEG $0344 \mathrm{wr}$ & Dacitic ash flow & 4 & $8.9 \pm 2.1$ & 19 of 19 & $298.2 \pm 3.7$ & $7.2 \pm 3.2$ & 0.21 & $725-1275$ & 100.00 .14 & $8.4 \pm 1.5$ \\
\hline SEG $0366 \mathrm{wr}$ & Andesitic lava flow & 2 & $24.6 \pm 8.5$ & 9 of 9 & $287.0 \pm 69.0$ & $36.0 \pm 34.0$ & 0.55 & $875-1230$ & 100.00 .32 & $23.5 \pm 5.8$ \\
\hline SEG $0303 \mathrm{wr}$ & Dacitic lava flow & 2 & $31.8 \pm 1.4$ & 10 of 10 & $295.6 \pm 3.6$ & $31.8 \pm 2.1$ & 0.80 & $900-1375$ & 100.00 .72 & $31.7 \pm 1.2$ \\
\hline SB87-56 wr & Rhyolitic lava flow & 4 & $31.9 \pm 1.1$ & 25 of 27 & $295.0 \pm 4.2$ & $34.0 \pm 1.9$ & 0.80 & $900-1300$ & 96.60 .34 & $33.2 \pm 0.9$ \\
\hline SEG $0345 \mathrm{wr}$ & Andesitic lava flow & 2 & $53.1 \pm 2.3$ & 11 of 11 & $294.9 \pm 4.1$ & $53.2 \pm 2.1$ & 0.42 & $850-1300$ & 100.01 .15 & $53.0 \pm 1.3$ \\
\hline SEG $0348 \mathrm{gm}$ & Basaltic lava flow & 3 & $72.6 \pm 16.6$ & 16 of 16 & $296.7 \pm 3.1$ & $40.0 \pm 29.0$ & 1.16 & $850-1275$ & 100.00 .06 & $65.6 \pm 13.7$ \\
\hline SEG $0301 \mathrm{wr}$ & Rhyolitic lava flow & 2 & $76.8 \pm 1.2$ & 10 of 10 & $295.4 \pm 5.5$ & $76.8 \pm 1.5$ & 0.55 & $875-1375$ & 100.01 .20 & $76.8 \pm 1.1$ \\
\hline SEG 0349 gm & Basaltic lava flow & 4 & $79.1 \pm 17.2$ & 16 of 17 & $295.3 \pm 3.3$ & $82.0 \pm 45.0$ & 0.23 & $875-1250$ & 92.60 .35 & $84.6 \pm 14.2$ \\
\hline SEG $0350 \mathrm{gm}$ & Basaltic lava flow & 3 & $105.1 \pm 24.1$ & 12 of 12 & $296.7 \pm 4.9$ & $84.0 \pm 71.0$ & 0.03 & $940-1250$ & 100.00 .24 & $98.1 \pm 18.5$ \\
\hline SEG $0335 \mathrm{gm}$ & Bas. andesitic lava flow & 2 & $115.3 \pm 16.0$ & 11 of 11 & $296.3 \pm 18.2$ & $111.7 \pm 84.3$ & 0.30 & $875-1325$ & 100.00 .26 & $116.5 \pm 13.6$ \\
\hline SEG $0343 \mathrm{wr}$ & Rhyodacitic dome & 2 & $144.1 \pm 2.7$ & 10 of 12 & $293.2 \pm 9.5$ & $143.3 \pm 6.2$ & 0.36 & $950-1250$ & 96.20 .00 & $141.9 \pm 2.2$ \\
\hline
\end{tabular}


neutron doses of 1.2 to $5.4 \times 10^{15} \mathrm{n} / \mathrm{cm}^{2}$. At the University of Wisconsin Rare Gas Geochronology Laboratory, the groundmass packets and mini-cores were incrementally heated in a double-vacuum resistance furnace attached to a $300 \mathrm{~cm}^{3}$ gas clean-up line. Prior to each incremental heating experiment, samples were degassed at $550-700{ }^{\circ} \mathrm{C}$ to potentially remove large amounts of atmospheric argon. Fully automated experiments consisted of 4-13 steps from 725-1450 ${ }^{\circ} \mathrm{C}$ with isotopic measurements and data reduction following the procedures in $[25,26]$. These measurements are critically dependent on characterizing the blank levels in the analytical system and the mass discrimination of the mass spectrometer. Blanks were measured over a range of temperature between 800 and $1350{ }^{\circ} \mathrm{C}$ prior to, and following, each sample and at $7.0 \times 10^{-18}$ and $2.1 \times 10^{-16}$ moles of ${ }^{36} \mathrm{Ar}$ and ${ }^{40} \mathrm{Ar}$, respectively, were atmospheric in composition and one to two orders of magnitude smaller than the sample signals, thus their impact on the age uncertainty has been minimized. Mass discrimination was measured 44 times during the analytical periods via an automated air pipette and varied between $1.0022 \pm 0.002$ and $1.0043 \pm 0.002$ per amu. Precise ages commonly require replicate experiments on several different subsamples from each lava or tuff. Basalts (50-53 wt.\% $\left.\mathrm{SiO}_{2}\right)$ and rhyolites $\left(69-71\right.$ wt. $\left.\% \mathrm{SiO}_{2}\right)$ yielded ages that have $2 \sigma$ analytical precisions of $\pm 10-15 \%$ and $\pm 1-2 \%$, respectively. Because isochron regressions agree with plateau ages and do not reveal evidence that excess argon is present in any of the lavas, we consider the plateau ages to give the best estimate of the time elapsed since eruption (Table 1).

\section{2. $U-$ Th isotopes}

Approximately 15-1500 mg of mineral separates were prepared from fresh, porphyritic lava samples by crushing, sieving to $250-500 \mu \mathrm{m}$, magnetic and density sorting, and hand picking under a binocular microscope to remove crystals or glass fragments containing inclusions. These highly purified separates and whole rock powders were spiked with a ${ }^{235} \mathrm{U}_{-}{ }^{229} \mathrm{Th}$ tracer and dissolved using $\mathrm{HF}-\mathrm{HNO}_{3}-$ $\mathrm{HCl}$ in Teflon beakers. Plagioclase separates required additional fuming in a $\mathrm{HF}-\mathrm{HClO}_{4}$ mixture. Silicate mineral separates and whole rock powders from andesitic to rhyolitic samples were pre-concentrated with $200-400 \mu \mathrm{l}$ of a $10,000 \mathrm{ppm}$ Fe solution. U and $\mathrm{Th}$ were co-precipitated with $\mathrm{Fe}(\mathrm{OH})_{3}$ using $\mathrm{NH}_{4} \mathrm{OH}$, and separated into clean Th and $\mathrm{U}$ fractions using BioRad AG 1 X8 200-400 mesh anion exchange resin in $1.2 \mathrm{ml}$ Teflon columns [35]. Isotopic measurements were done at the UW-Madison Isotope Laboratory using a GV Instruments Isoprobe MC-ICP-MS. Samples and standards were aspirated using a $50 \mu \mathrm{l} /$ min low flow nebulizer tip and an Aridus ${ }^{\circledR}$ desolvating nebulizer. Ions extracted from the ICP source were measured on a combination of Faraday and Daly detectors. The Th and $U$ fractions were measured separately on the mass spectrometer. Natural U $\left({ }^{238} U /{ }^{235} U=137.88\right)$ standard solutions were analyzed to determine instrumental mass fractionation. All measured $U$ and Th isotope ratios from spiked samples were corrected for mass bias based on the standard analyses. ${ }^{229} \mathrm{Th} /{ }^{230} \mathrm{Th}$ and ${ }^{230} \mathrm{Th} /{ }^{232} \mathrm{Th}$ ratios were also corrected for variations in the DalyFaraday gain, which was determined by measuring ${ }^{235} \mathrm{U}$ on the Daly and ${ }^{238} \mathrm{U}$ in a Faraday collector. The tail of the ${ }^{232} \mathrm{Th}$ peak on ${ }^{230} \mathrm{Th}$ was minimized by using the Wide Aperture Retarding Potential (WARP) filter [24]. External precision, reproducibility, and accuracy of $\mathrm{Th}$ and $\mathrm{U}$ isotope measurements were evaluated via repeated analyses of the Table Mountain Latite (TML) $(n=7)$ and AThO Icelandic rhyolite $(n=5)$ standards, which yielded weighted mean $\left({ }^{230} \mathrm{Th} /{ }^{232} \mathrm{Th}\right)$ activity ratios of $1.068 \pm 0.001(2 \sigma)$, and $1.018 \pm 0.002(2 \sigma)$, respectively (see complete results in electronic appendix). The $\left({ }^{230} \mathrm{Th} /{ }^{232} \mathrm{Th}\right)$ results of the rock standards are in agreement with those reported by ten other laboratories. Throughout the analytical period, nineteen measurements of a thorium reference solution, IRMM-035, yielded a ${ }^{232} \mathrm{Th} /{ }^{230} \mathrm{Th}$ ratio of $87,223 \pm 170(2 \sigma)$, well within error of the certified value of $87,100 \pm 592$. Total procedural blanks were typically $<70 \mathrm{pg}$ for $\mathrm{U}$ and $<90 \mathrm{pg}$ for Th. Because the sample to blank ratios were typically $>500$, no blank corrections were made.

\subsection{Sr Isotopes}

Sr isotopes were measured on 16 whole rock samples and mineral separates by thermal ionization mass spectrometry (TIMS) on a GV Instruments Sector 54 instrument at the University of Wisconsin-Madison. Sample dissolution and cation exchange procedures 
are the same as those described in [26]. Measurements used a dynamic multi-collector analysis routine, with exponential normalization to ${ }^{86} \mathrm{Sr} /{ }^{88} \mathrm{Sr}=0.1194$. Fourteen measurements of NIST SRM-987 yielded an ${ }^{87} \mathrm{Sr} /{ }^{86} \mathrm{Sr}$ ratio of $0.710267 \pm 0.000011$ (2 SD). Procedural blanks averaged $217 \mathrm{pg}$ for $\mathrm{Sr}$, which are negligible compared to the 2-10 ug of sample analyzed.

Three of the samples have a reddish, glassy groundmass, elevated loss on ignition (1.3-1.5 wt.\%) and total alkali contents (3.7-3.9 wt.\%) compared to other lavas of similar composition, which suggest that the matrices of these otherwise petrographically fresh rocks may have been slightly weathered. To circumvent potential secondary Sr additions, $100 \mathrm{mg}$ aliquots of fresh pyroxene or plagioclase from these and other samples were measured to constrain magmatic compositions.

\section{Results}

\section{1. ${ }^{40} \mathrm{Ar} /{ }^{39}$ Ar geochronology}

Thirty-three incremental heating experiments on 12 samples yielded largely concordant spectra with welldefined age plateaus comprising $93-100 \%$ of the ${ }^{39} \mathrm{Ar}$ released (Table 1). The 12 new age determinations, from previously undated samples, gave plateau ages between $141.9 \pm 2.2$ and $7.5 \pm 2.0 \mathrm{ka}$ and agree with relative stratigraphic position. The large ${ }^{40} \mathrm{Ar} /{ }^{39} \mathrm{Ar}$ age uncertainties of samples SEG-03-35, -48, -49, and -50 are mainly due to the low $\mathrm{K}_{2} \mathrm{O}$ contents of these lavas (0.6-0.8 wt.\%).

\subsection{U-Th isotopes}

All but one of the Seguam samples exhibit presentday $\mathrm{U}$ excesses ranging from 14 to $40 \%$, which are among the highest yet measured in the Aleutians $[32,33]$. The dacitic ash flow tuff (sample SEG 03 44) that was associated with caldera collapse at $\sim 9 \mathrm{ka}$ has $23 \%$ Th excess. U-Th fractionation between the major igneous minerals was sufficiently large to yield meaningful isochrons, where low U/Th ratios characterize plagioclase and high $\mathrm{U} / \mathrm{Th}$ ratios are found in magnetite. The relative precision of the U-Th mineral isochron ages is equal to or exceeds that of most published U-Th mineral ages, which are rarely constrained to better than $\pm 15 \%$ for lavas that are $<100$ kyrs old (see [1], for a review). We suspect that the improved precision is due to the relative simplicity of the system (i.e., very few cumulates or xenocrysts), high purity of the mineral separates, and the limited scatter about the isochron.

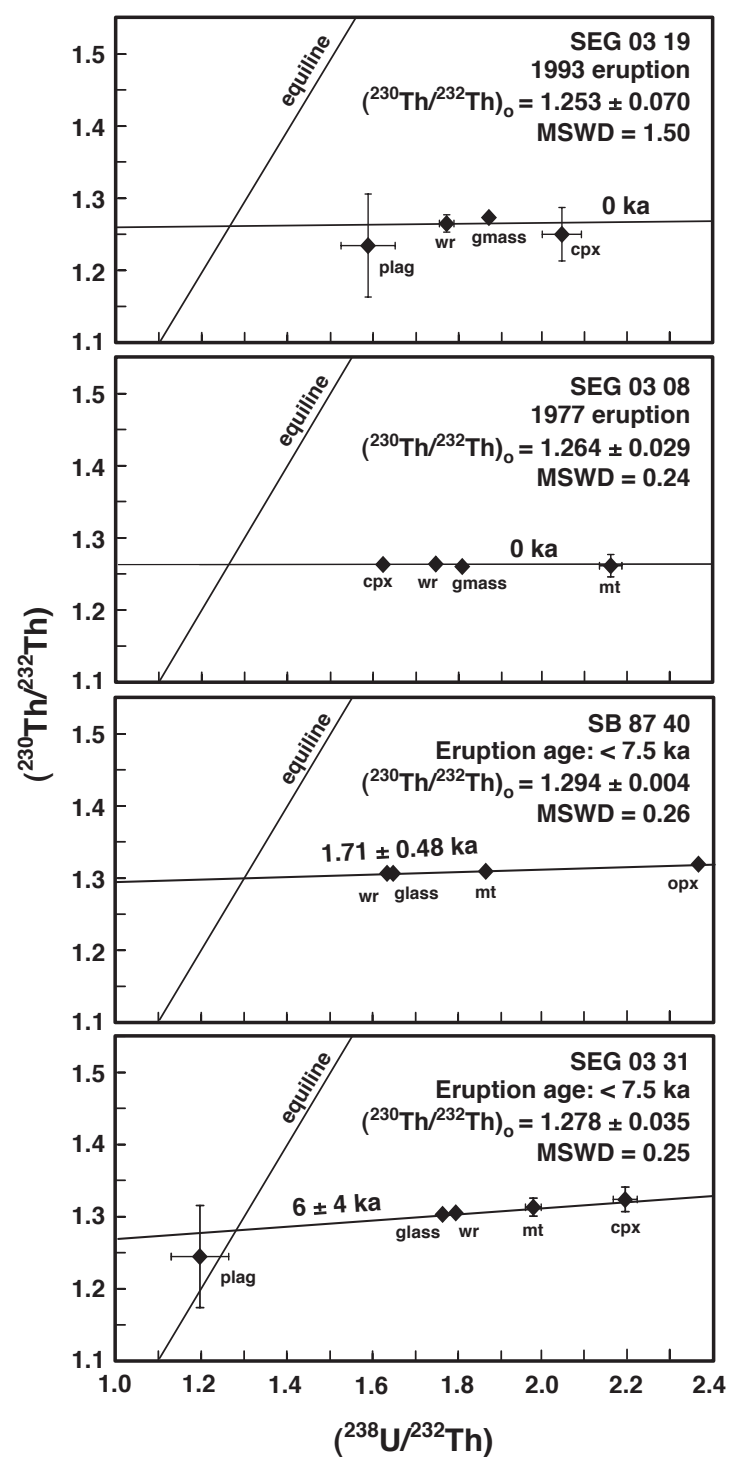

Fig. 2. U-Th mineral isochrons for four post-caldera collapse lavas from Seguam Island. All four mineral isochron ages are statistically indistinguishable from the eruptive ages. Data from Table 2. The ordinate of the intercept between the mineral isochron and the equiline gives the $\left({ }^{230} \mathrm{Th} /{ }^{232} \mathrm{Th}\right)_{0}$ ratio, which is that of the magma body at the time of crystallization. Abbreviations: plag, plagioclase; wr, whole rock; cpx, clinopyroxene; opx, orthopyroxene; mt, magnetite; gmass, groundmass. 

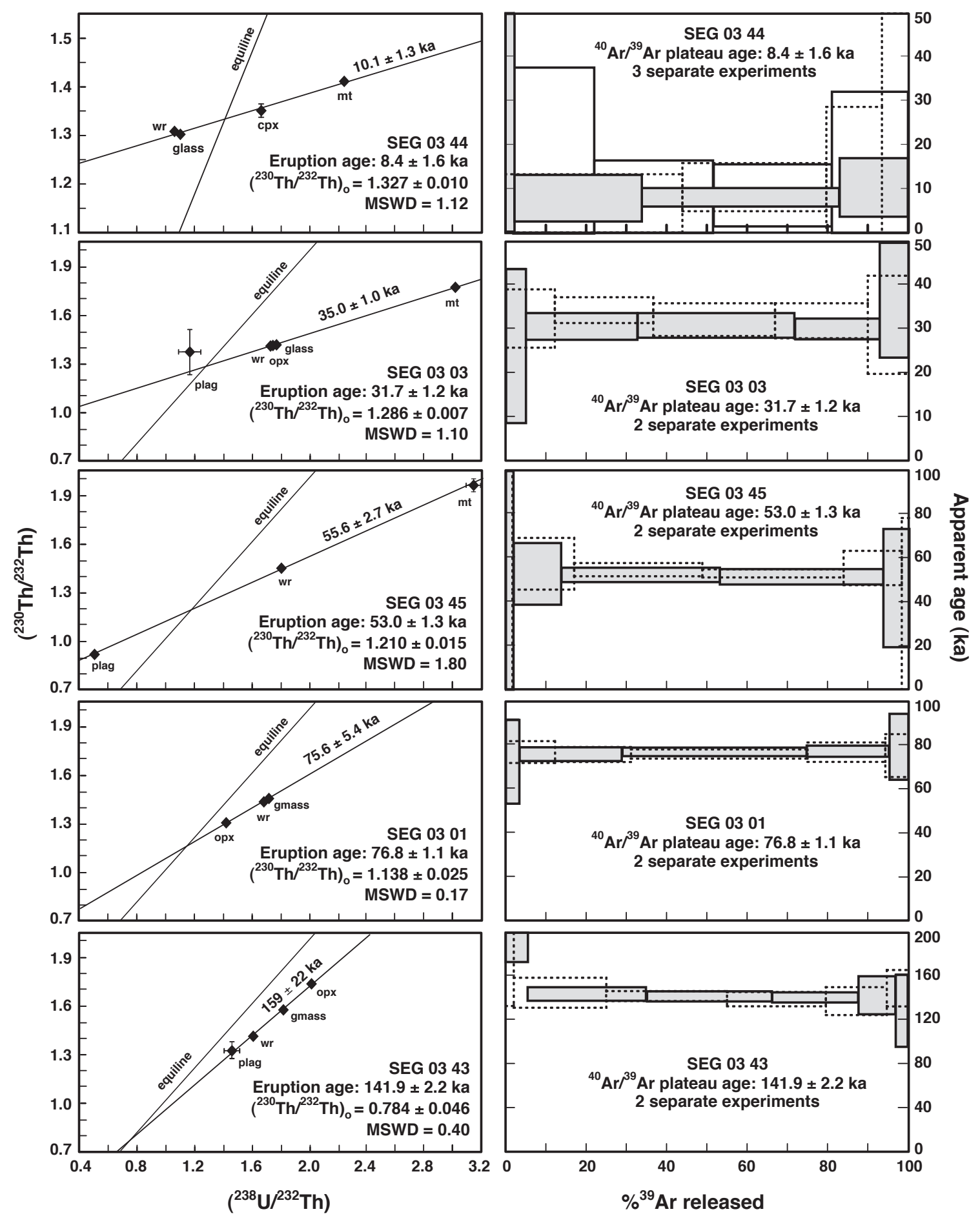

Fig. 3. U-Th mineral isochrons and ${ }^{40} \mathrm{Ar} /{ }^{39} \mathrm{Ar}$ age spectrum diagrams for the dacitic ignimbrite associated with the caldera collapse at $\sim 9 \mathrm{ka}$ and four pre-caldera lavas. Abbreviations are the same as those in Fig. 2. 
Table 2

$\mathrm{U}-\mathrm{Th}$ and $\mathrm{Sr}$ isotope data from Seguam Island lavas and mineral separates

\begin{tabular}{|c|c|c|c|c|c|c|c|c|c|c|}
\hline Sample & $\begin{array}{l}\mathrm{SiO}_{2} \\
\text { (wt.\%) }\end{array}$ & $\begin{array}{l}\frac{40}{{ }^{40} \mathrm{r}} \text { age } \\
(\mathrm{kr}) \\
(\mathrm{kr})\end{array}$ & Mineral & $\left(\frac{{ }^{238} \mathrm{U}}{{ }^{232} \mathrm{Th}}\right)$ & $\frac{{ }^{230} \mathrm{Th}}{{ }^{232} \mathrm{Th}}$ & $\begin{array}{l}\text { Th } \\
\text { (ppm) }\end{array}$ & $\begin{array}{l}\mathrm{U} \\
\text { (ppm) }\end{array}$ & $\begin{array}{l}\text { U-Th age } \\
\text { (ka) }\end{array}$ & $\left(\frac{{ }^{230} \mathrm{Th}}{{ }^{232} \mathrm{Th}}\right)_{0}$ & $\begin{array}{l}\frac{{ }^{87} \mathrm{Sr}}{{ }^{86} \mathrm{Sr}} \\
( \pm 2 \mathrm{SE})\end{array}$ \\
\hline \multirow[t]{4}{*}{ SEG 0319} & 53.5 & A.D. 1993 & wr & $1.773 \pm 0.017$ & $1.262 \pm 0.012$ & 1.025 & 0.599 & 0 & $1.253 \pm 0.070^{\mathrm{a}}$ & $0.703726 \pm 8$ \\
\hline & & & $\operatorname{cpx}$ & $2.042 \pm 0.046$ & $1.247 \pm 0.037$ & 0.029 & 0.020 & & & \\
\hline & & & plag & $1.588 \pm 0.063$ & $1.232 \pm 0.071$ & 0.009 & 0.005 & & & \\
\hline & & & gm & $1.872 \pm 0.015$ & $1.270 \pm 0.010$ & 1.138 & 0.702 & & & \\
\hline \multirow[t]{4}{*}{ SEG 0308} & 51.2 & A.D. 1977 & wr & $1.752 \pm 0.014$ & $1.264 \pm 0.010$ & 0.783 & 0.452 & 0 & $1.264 \pm 0.029^{\mathrm{a}}$ & $0.703700 \pm 9^{b}$ \\
\hline & & & gm & $1.813 \pm 0.012$ & $1.260 \pm 0.008$ & 0.926 & 0.553 & & & \\
\hline & & & $\mathrm{mt}$ & $2.162 \pm 0.026$ & $1.262 \pm 0.015$ & 0.937 & 0.668 & & & \\
\hline & & & cpx & $1.628 \pm 0.009$ & $1.264 \pm 0.007$ & 0.062 & 0.033 & & & \\
\hline \multirow[t]{4}{*}{ SB 8740} & 69.8 & $<7.5$ & wr & $1.639 \pm 0.004$ & $1.300 \pm 0.003$ & 4.556 & 2.460 & $1.71 \pm 0.48$ & $1.294 \pm 0.004^{\mathrm{a}}$ & $0.703571 \pm 10^{b}$ \\
\hline & & & gm & $1.648 \pm 0.004$ & $1.300 \pm 0.003$ & 4.859 & 2.639 & & & \\
\hline & & & opx & $2.360 \pm 0.004$ & $1.311 \pm 0.002$ & 0.563 & 0.438 & & & \\
\hline & & & $\mathrm{mt}$ & $1.866 \pm 0.009$ & $1.301 \pm 0.006$ & 1.212 & 0.745 & & & \\
\hline \multirow[t]{5}{*}{ SEG 0331} & 71.4 & $<7.5$ & wr & $1.796 \pm 0.011$ & $1.305 \pm 0.008$ & 4.116 & 2.437 & $6.0 \pm 4.0$ & $1.278 \pm 0.035^{\mathrm{a}}$ & $0.703612 \pm 10$ \\
\hline & & & gm & $1.766 \pm 0.010$ & $1.304 \pm 0.007$ & 4.088 & 2.379 & & & \\
\hline & & & $\mathrm{mt}$ & $1.978 \pm 0.019$ & $1.313 \pm 0.012$ & 0.722 & 0.471 & & & \\
\hline & & & cpx & $2.193 \pm 0.028$ & $1.324 \pm 0.017$ & 0.384 & 0.278 & & & \\
\hline & & & plag & $1.197 \pm 0.067$ & $1.245 \pm 0.070$ & 0.138 & 0.055 & & & \\
\hline SEG 0332 & 70.8 & $7.5 \pm 2.0$ & wr & $1.712 \pm 0.018$ & $1.333 \pm 0.007$ & 4.461 & 2.517 & & $1.306 \pm 0.007$ & $0.703601 \pm 7$ \\
\hline \multirow[t]{4}{*}{ SEG 0344} & 64.5 & $8.4 \pm 1.5$ & wr & $1.066 \pm 0.006$ & $1.309 \pm 0.010$ & 2.151 & 0.756 & $10.1 \pm 1.3$ & $1.327 \pm 0.010^{\mathrm{a}}$ & $0.703622 \pm 7$ \\
\hline & & & gl & $1.106 \pm 0.007$ & $1.303 \pm 0.011$ & 2.559 & 0.933 & & & \\
\hline & & & cpx & $1.668 \pm 0.012$ & $1.351 \pm 0.014$ & 0.095 & 0.052 & & & \\
\hline & & & $\mathrm{mt}$ & $2.247 \pm 0.011$ & $1.410 \pm 0.010$ & 0.441 & 0.326 & & & \\
\hline SEG 0366 & 62.8 & $23.5 \pm 5.8$ & wr & $1.686 \pm 0.005$ & $1.383 \pm 0.004$ & 3.204 & 1.780 & & $1.310 \pm 0.004$ & $0.703730 \pm 8$ \\
\hline \multirow[t]{5}{*}{ SEG 0303} & 67.9 & $31.7 \pm 1.2$ & wr & $1.733 \pm 0.012$ & $1.411 \pm 0.010$ & 3.546 & 2.026 & $35.0 \pm 1.0$ & $1.286 \pm 0.007^{\mathrm{a}}$ & $0.703676 \pm 8$ \\
\hline & & & gm & $1.777 \pm 0.014$ & $1.421 \pm 0.011$ & 3.734 & 2.187 & & & \\
\hline & & & $\mathrm{mt}$ & $3.014 \pm 0.009$ & $1.766 \pm 0.005$ & 0.336 & 0.334 & & & \\
\hline & & & opx & $1.755 \pm 0.016$ & $1.413 \pm 0.013$ & 0.309 & 0.179 & & & \\
\hline & & & plag & $1.161 \pm 0.078$ & $1.373 \pm 0.139$ & 0.059 & 0.022 & & & \\
\hline SB 8756 & 69.5 & $33.2 \pm 0.9$ & wr & $1.798 \pm 0.011$ & $1.425 \pm 0.008$ & 4.074 & 2.415 & & $1.291 \pm 0.007$ & $0.703680 \pm 10^{b}$ \\
\hline \multirow[t]{3}{*}{ SEG 0345} & 62.4 & $53.0 \pm 1.3$ & wr & $1.806 \pm 0.015$ & $1.453 \pm 0.012$ & 3.325 & 1.980 & $55.6 \pm 2.7$ & $1.210 \pm 0.015^{\mathrm{a}}$ & $0.703674 \pm 8$ \\
\hline & & & $\mathrm{mt}$ & $3.142 \pm 0.050$ & $1.960 \pm 0.038$ & 0.361 & 0.373 & & & \\
\hline & & & plag & $0.505 \pm 0.011$ & $0.923 \pm 0.020$ & 0.060 & 0.010 & & & \\
\hline \multirow[t]{2}{*}{ SEG 0348} & 52.2 & $65.6 \pm 13.7$ & wr & $1.576 \pm 0.011$ & $1.366 \pm 0.010$ & 1.414 & 0.734 & & $1.182 \pm 0.010$ & \\
\hline & & & $\operatorname{cpx}$ & & & & & & & $0.703694 \pm 10$ \\
\hline \multirow[t]{3}{*}{ SEG 0301} & 70.4 & $76.8 \pm 1.1$ & wr & $1.691 \pm 0.005$ & $1.415 \pm 0.004$ & 4.438 & 2.473 & $75.6 \pm 5.4$ & $1.138 \pm 0.025^{\mathrm{a}}$ & $0.703664 \pm 10$ \\
\hline & & & gm & $1.715 \pm 0.006$ & $1.426 \pm 0.005$ & 4.428 & 2.503 & & & \\
\hline & & & opx & $1.423 \pm 0.006$ & $1.281 \pm 0.005$ & 0.633 & 0.297 & & & $0.703669 \pm 10$ \\
\hline \multirow[t]{2}{*}{ SEG 0349} & 52.4 & $84.6 \pm 14.2$ & wr & $1.600 \pm 0.015$ & $1.381 \pm 0.013$ & 1.376 & 0.726 & & & \\
\hline & & & cpx & & & & & & & $0.703712 \pm 7$ \\
\hline \multirow[t]{2}{*}{ SEG 0350} & 52.5 & $98.1 \pm 18.5$ & wr & $1.619 \pm 0.011$ & $1.386 \pm 0.010$ & 1.063 & 0.567 & & $1.122 \pm 0.013$ & $0.703628 \pm 8$ \\
\hline & & & $\operatorname{cpx}$ & & & & & & & $0.703637 \pm 8$ \\
\hline \multirow[t]{2}{*}{ SEG 0335} & 54.7 & $116.5 \pm 13.8$ & wr & $1.693 \pm 0.018$ & $1.435 \pm 0.015$ & 1.562 & 0.872 & & $1.044 \pm 0.010$ & \\
\hline & & & cpx & & & & & & & $0.703683 \pm 8$ \\
\hline \multirow[t]{4}{*}{ SEG 0343} & 68.7 & $141.9 \pm 2.2$ & wr & $1.607 \pm 0.007$ & $1.415 \pm 0.010$ & 4.171 & 2.209 & $159.0 \pm 22.0$ & $0.784 \pm 0.046^{\mathrm{a}}$ & $0.703747 \pm 8$ \\
\hline & & & plag & $1.454 \pm 0.056$ & $1.328 \pm 0.052$ & 0.034 & 0.016 & & & $0.703733 \pm 10$ \\
\hline & & & opx & $2.019 \pm 0.012$ & $1.734 \pm 0.014$ & 0.443 & 0.295 & & & \\
\hline & & & gm & $1.813 \pm 0.014$ & $1.573 \pm 0.012$ & 4.087 & 2.443 & & & \\
\hline
\end{tabular}

Abbreviations: wr, whole rock; gm, ground mass; cpx, clinopyroxene; opx, orthopyroxene; gl, glass; mt, magnetite; plag, plagioclase. All analytical $\mathrm{U}$ and $\mathrm{Th}$ isotope uncertainties are reported at $2 \sigma$ precision. Sr isotope uncertainties reported at 2 standard error (2 SE). Parentheses around nuclides denote activity.

Decay constants used for activity calculations: ${ }^{238} \mathrm{U}, 1.5513 \times 10^{-10} / \mathrm{yr} ;{ }^{230} \mathrm{Th}, 9.217 \times 10^{-6} / \mathrm{yr} ;{ }^{232} \mathrm{Th}, 4.948 \times 10^{-11} / \mathrm{yr}$.

${ }^{\text {a }}\left({ }^{230} \mathrm{Th} /{ }^{232} \mathrm{Th}\right)_{0}$ ratios determined from intersection of isochron and equiline.

${ }^{b}$ Data from Jicha et al. [26]. 


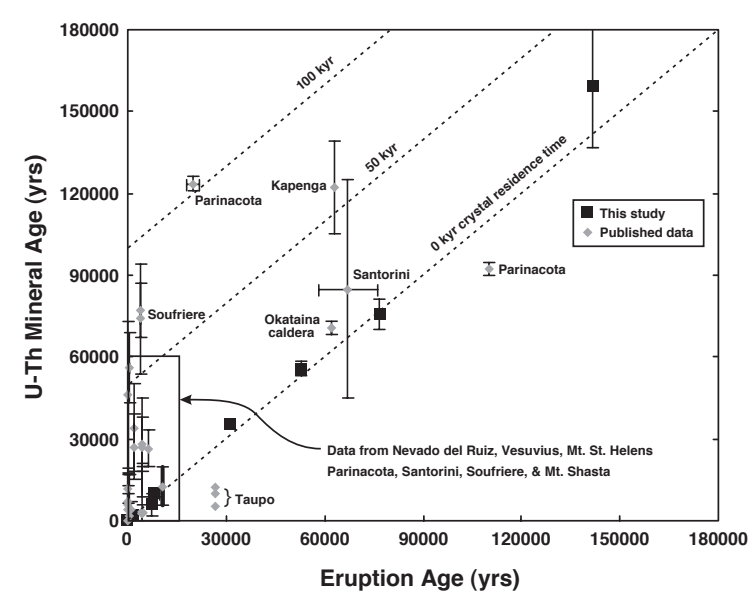

Fig. 4. U-Th mineral ages (yrs) plotted against independently determined Eruptive age (yrs) for arc lavas. Dashed lines represent 0,50 , and $100 \mathrm{kyr}$ crystal residence times. Published data from [1] and references therein.

Minerals and glass from basalts erupted in 1977 and 1993 define zero-age isochrons, and those from two $<7.5$ ka rhyolites, an 8.4 ka dacitic ash flow tuff, $53 \mathrm{ka}$ andesite, $76.8 \mathrm{ka}$ rhyolite, and a $142 \mathrm{ka}$ rhyodacite gave isochrons that are all in agreement with their eruption ages as determined by ${ }^{40} \mathrm{Ar} /{ }^{39} \mathrm{Ar}$ plateau ages (Table 2; Figs. 2 and 3). A rhyolite that has an ${ }^{40} \mathrm{Ar} /{ }^{39} \mathrm{Ar}$ age of $31.7 \pm 1.2 \mathrm{ka}$ yielded a U-Th isochron age of $35.0 \pm 1.0 \mathrm{ka}$, which is $2-5 \mathrm{kyrs}$ older than the eruptive age. $\left({ }^{230} \mathrm{Th} /{ }^{232} \mathrm{Th}\right)_{0}$ ratios for each of the mineral isochrons were determined from the intersection of the isochrons with the equiline (Figs. 2 and 3). Because most mineral isochrons ages are within error of the eruptive ages (Figs. 3 and 4), "age-corrected" initial $\left({ }^{230} \mathrm{Th} /{ }^{232} \mathrm{Th}\right)_{0}$ ratios were calculated for the seven prehistoric samples for which no $\mathrm{U}-\mathrm{Th}$ isochron data are available. Given the measured whole rock $\left({ }^{230} \mathrm{Th} /{ }^{232} \mathrm{Th}\right)$ and $\left({ }^{238} \mathrm{U} /{ }^{232} \mathrm{Th}\right)$ ratios of these seven samples, the initial $\left({ }^{230} \mathrm{Th} /{ }^{232} \mathrm{Th}\right)_{0}$ ratios were calculated using:

$$
\begin{aligned}
\left(\frac{{ }^{230} \mathrm{Th}}{{ }^{232} \mathrm{Th}}\right)_{\text {measured }}= & \left(\frac{{ }^{230} \mathrm{Th}}{{ }^{232} \mathrm{Th}}\right)_{\text {initial }} e^{-\lambda_{230} t} \\
& +\left(\frac{{ }^{238} \mathrm{U}}{{ }^{232} \mathrm{Th}}\right)\left(1-e^{-\lambda_{230} t}\right)
\end{aligned}
$$

where $t$ is the eruptive age as determined by ${ }^{40} \mathrm{Ar} /{ }^{39} \mathrm{Ar}$ dating, and $\lambda_{230}$ is the decay constant for ${ }^{230} \mathrm{Th}$, which

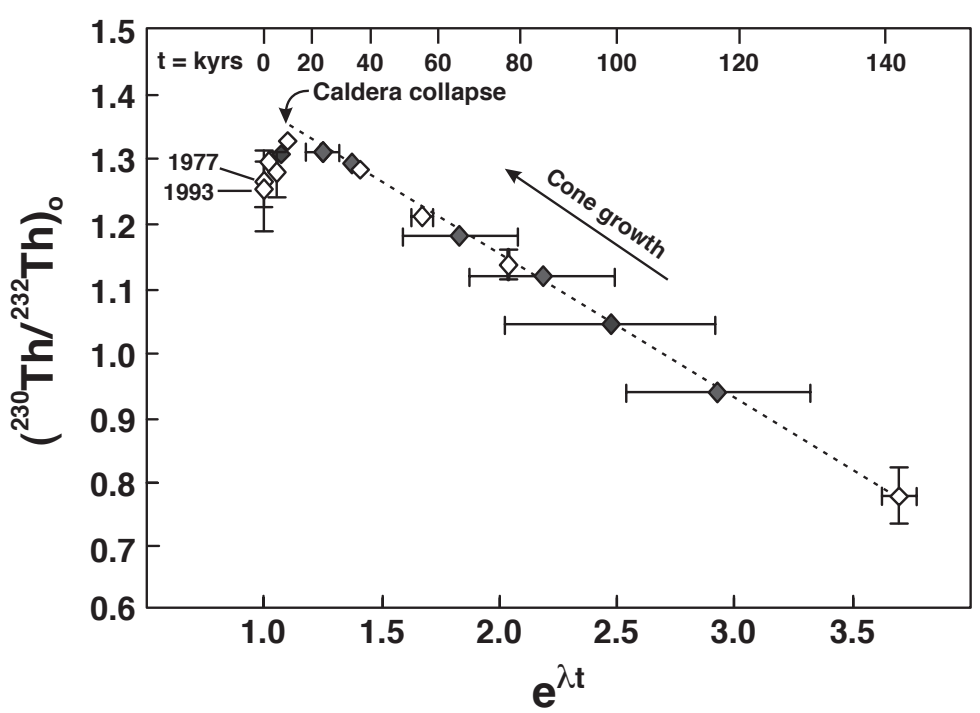

Fig. 5. Evolution of $\left({ }^{230} \mathrm{Th} /{ }^{232} \mathrm{Th}\right)_{0}$ measured in Seguam Island lavas as a function of eruptive age (expressed as $\left.e^{\lambda t}\right) .\left({ }^{230} \mathrm{Th} /{ }^{232} \mathrm{Th}\right)_{0}$ ratios are plotted as whole rock ${ }^{40} \mathrm{Ar} /{ }^{39} \mathrm{Ar}$ age-corrected ratios (filled symbols), or as those determined from the isochron diagrams (open symbols) in Figs. 2 and 3. Uncertainties in the $\left({ }^{230} \mathrm{Th} /{ }^{232} \mathrm{Th}\right)_{0}$ ratios are discussed in the text. Errors in $e^{\lambda t}$ represent ${ }^{40} \mathrm{Ar} /{ }^{39} \mathrm{Ar}$ or U-Th mineral isochron age uncertainties $(2 \sigma)$. Dashed line represents $130 \mathrm{kyrs}$ of undisturbed ${ }^{230} \mathrm{Th}$ ingrowth modeled from the $\left({ }^{230} \mathrm{Th} /{ }^{232} \mathrm{Th}\right)_{0}$ and whole rock $\left({ }^{238} \mathrm{U} /{ }^{232} \mathrm{Th}\right)$ of the 142 ka lava. $\left.{ }^{230} \mathrm{Th} /{ }^{232} \mathrm{Th}\right)_{0}$ variations in Seguam Island lavas from $142-9$ ka closely match those of the ${ }^{230} \mathrm{Th}$ ingrowth model until caldera collapse at $9 \mathrm{ka}$. 
is $9.217 \times 10^{-6} / \mathrm{yr}$. The errors reported for the "agecorrected" $\left({ }^{230} \mathrm{Th} /{ }^{232} \mathrm{Th}\right)_{0}$ ratios are equal to the analytical uncertainties, whereas errors of the $\left({ }^{230} \mathrm{Th} /{ }^{232} \mathrm{Th}\right)_{0}$ ratios determined from the isochrons are proportional to the uncertainty in the slope of the isochron.

Initial $\left({ }^{230} \mathrm{Th} /{ }^{232} \mathrm{Th}\right)_{0}$ ratios of ten lavas linearly increase from 0.78 to 1.33 between 142 and 9 ka when plotted versus $e^{\lambda t}$ as initially proposed in [6], whereas basalts and rhyolites that post-date caldera collapse abruptly decrease from 1.31 to 1.25 during the Holocene (Fig. 5). Prior to this study, only one Th isotope composition had been determined from Seguam on a Holocene basaltic lava flow $\sim 5 \mathrm{~km}$ southwest of Pyre Peak [32] (Fig. 1), but the $\left({ }^{230} \mathrm{Th} /{ }^{232} \mathrm{Th}\right)_{0}$ ratio of this lava, like other Holocene-historic lavas, is lower than those that erupted immediately prior to caldera collapse. The 142-53 ka Seguam lavas have $\left({ }^{230} \mathrm{Th} /{ }^{232} \mathrm{Th}\right)_{0}$ ratios of 0.78 to 1.21 , which are distinctively lower than those of most Aleutian Island arc lavas which range from 1.3-1.4) [32,33].

\subsection{Sr Isotopes}

The ${ }^{87} \mathrm{Sr} /{ }^{86} \mathrm{Sr}$ ratios of 16 whole rock and phenocryst samples lie between 0.70360 and 0.70374 , well within the narrow range of ratios $(0.70357-0.70375)$ reported earlier [14,26,27] from 28 Seguam lavas of Latest Pleistocene-historic age (Fig. 6). ${ }^{87} \mathrm{Sr} /{ }^{86} \mathrm{Sr}$

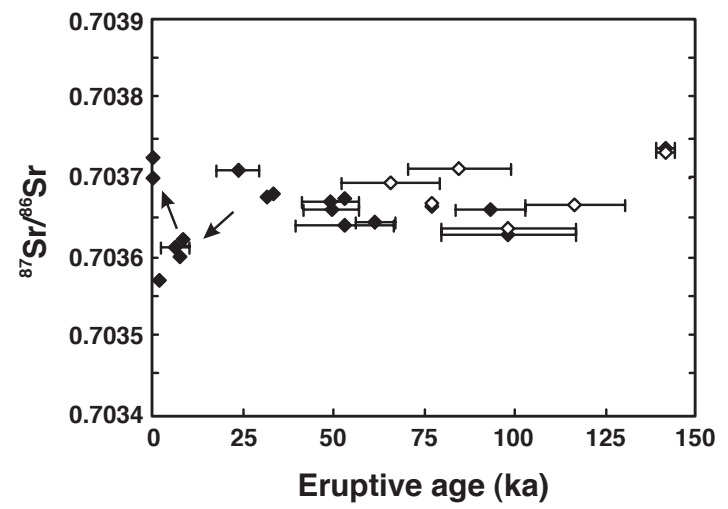

Fig. $6 .{ }^{87} \mathrm{Sr} /{ }^{86} \mathrm{Sr}$ vs. eruptive age (ka) for Seguam Island lavas. Eruptive ages are constrained via ${ }^{40} \mathrm{Ar} /{ }^{39} \mathrm{Ar}$ geochronology. Dacitic to rhyolitic lavas that erupted after the $9 \mathrm{ka}$ caldera collapse have lower ${ }^{87} \mathrm{Sr} /{ }^{86} \mathrm{Sr}$ ratios than the pre-collapse Pleistocene lavas, whereas the basaltic lavas erupted in 1977 and 1993 are among the most radiogenic on the island. Open symbols represent pyroxene separates. Data from Table 2 and [26]. ratios of minerals measured in samples suspected to be slightly weathered are indistinguishable from those of fresh whole rocks or minerals separated from other samples. Notably, dacitic to rhyolitic lavas that erupted after the caldera collapsed at $9 \mathrm{ka}$ are lower in ${ }^{87} \mathrm{Sr} /{ }^{86} \mathrm{Sr}$ ratios than the pre-collapse lavas (Fig. 6). The shift to less radiogenic ${ }^{87} \mathrm{Sr} /{ }^{86} \mathrm{Sr}$ ratios after collapse of the caldera is mirrored by the drop in $\left({ }^{230} \mathrm{Th} /{ }^{232} \mathrm{Th}\right.$ ) ratios (Fig. 5), although ${ }^{87} \mathrm{Sr} /{ }^{86} \mathrm{Sr}$ ratios of the basaltic lavas erupted in 1977 and 1993 are among the most radiogenic on the island. There is no correlation between $\mathrm{SiO}_{2},{ }^{87} \mathrm{Sr} /{ }^{86} \mathrm{Sr}$, or $\delta^{18} \mathrm{O}$ which we take as evidence that open-system processes had minimal influence on the magmas erupted at Seguam $[14,28]$.

\section{Discussion}

The observation that $\mathrm{U}-\mathrm{Th}$ isochrons defined by minerals + whole rock + groundmass give ages identical to the ${ }^{40} \mathrm{Ar} /{ }^{39} \mathrm{Ar}$ eruptive ages for eight of the nine lavas and tephras indicates that $\mathrm{Th}$ isotope homogeneity prevailed in each magma at the time of crystallization. Moreover, this implies that postcrystallization residence times for the various mineral phases in the magma must have been very brief (i.e., less than a few thousand years). Rapid decompression and devolatilization may be an effective mechanism that promotes crystallization of Aleutian basalt [36]. Moreover, growth of phenocrysts in a rapidly ascending magma provides a scenario conductive to fractionation of buoyant melt from crystals and strong differentiation en route to the surface. The isochronous relationship between erupted phenocrysts and glass (Figs. 2 and 3) suggests that these crystals grew after differentiation, and perhaps immediately prior to eruption in most cases. In one case, however, the ${ }^{238} \mathrm{U}-{ }^{230} \mathrm{Th}$ isochron age of $35.0 \pm 1.0 \mathrm{ka}$ obtained from a $31.7 \pm 1.2 \mathrm{ka}$ rhyolite likely represents a brief $\sim 2-5 \mathrm{kyr}$ period of crystal residence in the magma prior to eruption. Alternatively, the difference between the U-Th isochron and eruptive ages of this particular rhyolite could reflect the presence of older cores, or perhaps mixing of phenocrysts with older crystals derived from either wall rocks or early-formed [20,37]. Both explanations seem improbable because the groundmass and 
phenocryst phases are isochronous (Fig. 3), suggesting that bulk crystal-liquid chemical equilibrium prevailed. Furthermore, electron probe microanalyses of numerous magnetite crystals separated from this sample indicate that this phase, which anchors the isochron, is not compositionally zoned.

The only ignimbrite studied (sample SEG 03 44, formed during stratocone collapse) is unusual in three ways: 1) it has a much lower $\mathrm{U} / \mathrm{Th}$ ratio than any of the lava flows measured, such that its whole-rock composition plots to the left of the equiline (Fig. 3), 2) it contains trace amounts of anhedral, strongly resorbed biotite, suggesting that this magma may have assimilated small amounts of hydrous crust before the caldera-forming eruption, and 3) apatite is a relatively abundant phenocryst in the moderately welded glass shards and occurs as inclusions within the plagioclase and clinopyroxene phenocrysts. If assimilation of crust modified the $\mathrm{U} / \mathrm{Th}$ ratio of this magma body, it must have occurred before crystallization of the clinopyroxene and magnetite that together with the glass define an isochron. Because the partition coefficient for Th $\left(\mathrm{D}_{\mathrm{Th}}\right)$ in apatite is much greater than that of $U\left(D_{U}\right)$ and because the $U$ and $T h$ contents in apatite are much higher than other major igneous minerals [38], apatite fractionation may also partly explain the Th excess found in this ignimbrite.

Magmatic evolution from 142 to 9 ka cannot be the result of fractionation in a single, slowly cooling chamber because the composition of the eruptive products during this period alternated in a non-systematic way over time between basaltic and rhyolitic (Table 2), and the crystal residence times are two orders of magnitude shorter than the $130 \mathrm{kyr}$ period of volcanic activity. We also find it highly unlikely that the monotonic increase in $\left({ }^{230} \mathrm{Th} /{ }^{232} \mathrm{Th}\right)_{0}$ ratios seen in magmas which share a narrow range of $U / T h$ ratios between 1.6 and 1.8 reflects either the repeated melting of single, aging, U-enriched mantle source, or modification of this source by successive additions of slab fluid (Fig. 7). The former scenario would require melting previously modified mantle on several occasions such that: 1) $U$ was not further fractionated from Th during melting, 2) each melt had the same U/Th ratio, and 3) these melts ascended through $>75 \mathrm{~km}$ of mantle and crust without modification to the U/Th or $\left({ }^{230} \mathrm{Th} /{ }^{232} \mathrm{Th}\right)_{0}$ ratios. The latter case would require many discrete additions of slab fluid to the mantle,
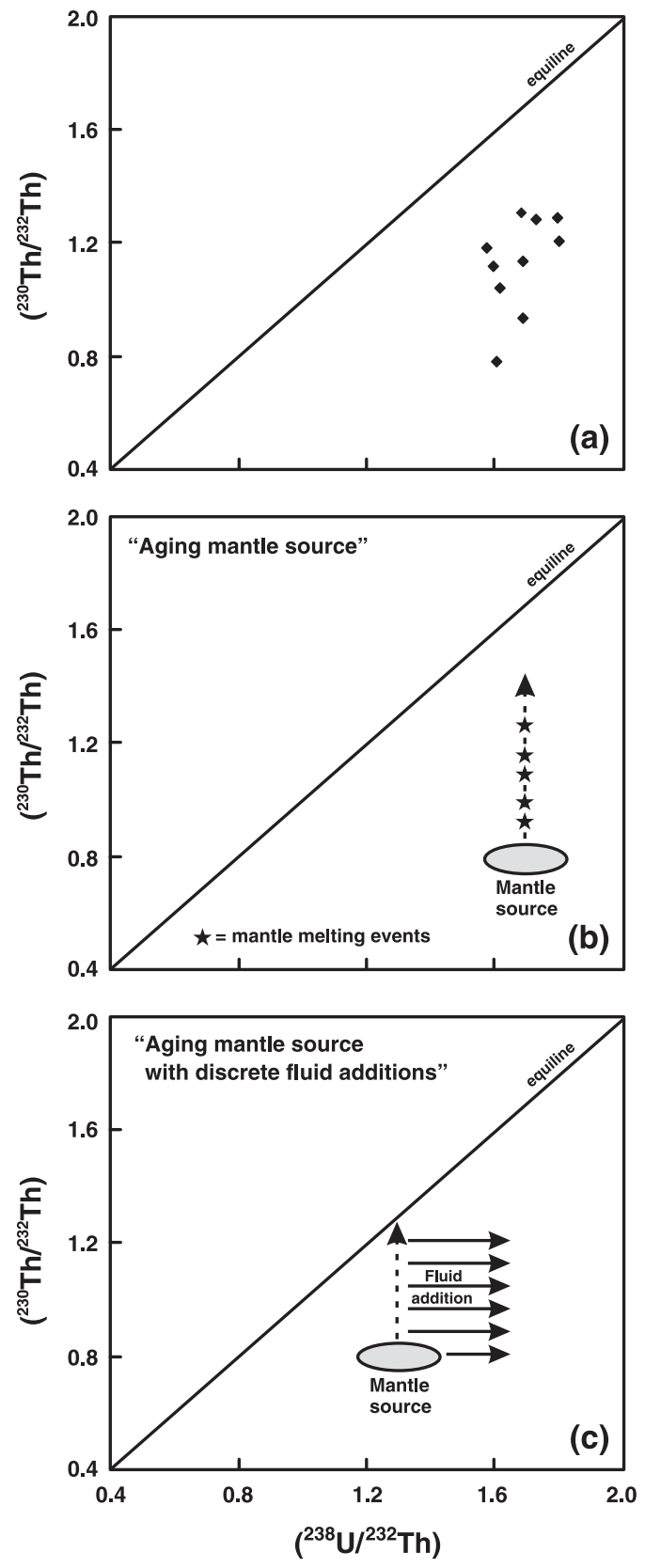

Fig. 7. (a) Plot of age-corrected $\left({ }^{230} \mathrm{Th} /{ }^{232} \mathrm{Th}\right)$ vs. $\left({ }^{238} \mathrm{U} /{ }^{232} \mathrm{Th}\right)$ for Seguam lavas erupted prior to the 9 ka caldera collapse. (b) Model of mantle melting events required to produce the observed compositions in (a) that involves an aging mantle source in secular disequilibrium and a sequence of non-fluid induced melting events to produce magmas with the appropriate $\left({ }^{230} \mathrm{Th} /{ }^{232} \mathrm{Th}\right)$ ratios. (c) Another model that involves an aging mantle source that is repeatedly modified by a fluid, which produces magmas with similar $\left({ }^{238} \mathrm{U} /{ }^{232} \mathrm{Th}\right)$ ratios. 
such that the melt produced via fluid-rock interaction repeatedly achieved the same $\mathrm{U} / \mathrm{Th}$ ratio, but at progressively higher $\left({ }^{230} \mathrm{Th} /{ }^{232} \mathrm{Th}\right)_{0}$ ratios; again each successive partial melt would have to ascend through $>75 \mathrm{~km}$ of mantle and crust without modification of these ratios, which is unlikely. Instead, it is more plausible to explain the near constant $\mathrm{U} / \mathrm{Th}$ ratio of the spectrum of erupted magmas and the progressive change in $\left({ }^{230} \mathrm{Th} /{ }^{232} \mathrm{Th}\right)_{0}$ via intra-crustal processes.

We interpret the monotonic increase in $\left({ }^{230} \mathrm{Th} /\right.$ $\left.{ }^{232} \mathrm{Th}\right)_{0}$ ratios with time prior to caldera collapse to reflect ${ }^{230} \mathrm{Th}$ ingrowth in a body of basaltic magma that remained closed with respect to $\mathrm{Th}$ and $\mathrm{U}$ addition or loss for over 130 kyrs (Fig. 5). Allègre and Condomines [6] proposed a similar model of closed system evolution for Irazu volcano in Costa Rica over a period of 140 kyrs. Based on the data from the 142 ka sample, which has a $\left({ }^{230} \mathrm{Th} /{ }^{232} \mathrm{Th}\right)_{0}$ ratio of 0.784 (determined from the mineral isochron) and a whole rock $\left({ }^{238} \mathrm{U} /{ }^{232} \mathrm{Th}\right)$ ratio of $1.607,132 \mathrm{kyrs}$ of closedsystem ${ }^{230} \mathrm{Th}$ ingrowth would produce a magma that had a $\left({ }^{230} \mathrm{Th} /{ }^{232} \mathrm{Th}\right)_{0}$ ratio of 1.36 , which is similar to the ratio of 1.33 that was determined for the $9 \mathrm{ka}$ dacitic ignimbrite. Therefore, the hypothesis of radiogenic ingrowth is supported by the $\left({ }^{230} \mathrm{Th} /{ }^{232} \mathrm{Th}\right)_{0}$ ratios measured for the lavas erupted between 142 and $9 \mathrm{ka}$ (Fig. 5). The abrupt shift in magmatic evolution toward successively lower $\left({ }^{230} \mathrm{Th} /{ }^{232} \mathrm{Th}\right)_{0}$ ratios beginning immediately after stratocone collapse at $\sim 9$ ka seems likely to reflect the influx of magma into the system, which had lower $\left({ }^{230} \mathrm{Th} /{ }^{232} \mathrm{Th}\right)_{0}$ and ${ }^{87} \mathrm{Sr} /{ }^{86} \mathrm{Sr}$ ratios (Figs. 5 and 6 ), or the mixing of this newly arrived magma with melt that remained in the deep reservoir following caldera formation.

Existence of a deep, closed basaltic reservoir for $>100$ kyrs that has undergone negligible crystallization would require minimal heat loss to the surrounding rocks during this protracted period of magma storage. Crystallization and cooling of a closed magma chamber can also be inhibited due to heating from successive injections of basaltic sills emplaced beneath the base of the magma reservoir [39], although the Th isotope data would not allow these to mix. The trend in $\left({ }^{230} \mathrm{Th} /{ }^{232} \mathrm{Th}\right)_{0}$ ratios of Seguam lavas erupted between 142 and 9 ka precludes partial melting of the surrounding crust or mixing between the long-lived reservoir and other batches of magma because these processes would deflect the $\left({ }^{230} \mathrm{Th} /{ }^{232} \mathrm{Th}\right)_{0}$ ratios off the linear trend. Furthermore, it has been suggested that melting of old lower crust occurs after $\sim 1$ myr of sustained basaltic magma input and only then if the crust is hydrous [39]. Thus, assimilation of old crust may be suppressed for basaltic magmas percolating through or residing in the middle to lower crust.

The $\left({ }^{230} \mathrm{Th} /{ }^{232} \mathrm{Th}\right)$ ratio of 0.784 for the rhyodacite erupted at $142 \mathrm{ka}$ is lower than $\left({ }^{230} \mathrm{Th} /{ }^{232} \mathrm{Th}\right)_{0}$ ratios previously measured on historically erupted lavas from this arc $[32,33]$, suggesting that this magma was derived from a compositionally different mantle source than the historic lavas and domes prior to becoming isolated for 130 kyrs. Sigmarsson et al. [40] proposed that low $\left({ }^{230} \mathrm{Th} /{ }^{232} \mathrm{Th}\right)$ ratios in SVZ lavas were characteristic of an origin from a mantle wedge modified by pelagic and terrigenous sediments. In addition to lowering the $\left({ }^{230} \mathrm{Th} /{ }^{232} \mathrm{Th}\right)$ ratio of the sub-arc mantle, sediment input will increase its ${ }^{87} \mathrm{Sr} /{ }^{86} \mathrm{Sr}$ composition. The ${ }^{87} \mathrm{Sr} /{ }^{86} \mathrm{Sr}$ ratios of Seguam lavas are elevated relative to those of other Aleutian arc volcanoes and are thought to reflect modification of the mantle wedge via enhanced subduction of sediments in the Amlia Fracture Zone [26,41]. The 142 ka rhyodacite has the highest ${ }^{87} \mathrm{Sr} /{ }^{86} \mathrm{Sr}$ ratio measured on Seguam (Fig. 6) thereby supporting an origin of the earlier erupted magmas from a strongly sediment-modified mantle wedge.

The post-collapse lavas, which likely bypassed the basaltic melt lens, have $\left({ }^{230} \mathrm{Th} /{ }^{232} \mathrm{Th}\right)_{0}$ ratios $(1.25-1.31)$ that are similar to other Holocene-historic Aleutian arc lavas [32,33], but much higher than the pre-collapse lavas. If the post-collapse magmas rose directly from the mantle and bypassed the basaltic reservoir as we have suggested, and if the source to surface transit occurred in less than 8000 years, they should exhibit Ra excesses. The Holocene basalt flow analyzed by [32] has a $12 \% \mathrm{Ra}$ excess, which supports the idea that the post-collapse magmas rose rapidly from a mantle source that has a $\left({ }^{230} \mathrm{Th} /{ }^{232} \mathrm{Th}\right)_{0}$ ratio that is significantly different than the one that produced magma 142 kyrs ago.

We envision that each erupted magma illustrated in Fig. 5 represents a small volume tapped from a stagnant lens of basaltic melt perched within a hot, mainly crystalline mush zone that comprises an interconnected network of sills and dikes that were partly solidified from mantle-derived basalt within the lower to middle 
crust (Fig. 8) [39]. Given sufficient flux of mantlederived magma from below, a deep crustal hot zone can build over periods of $10^{5}$ to $10^{6}$ years and take equally long to decay to background geothermal gradients once magma supply has diminished [39]. The longevity of a crystal-poor, thermally-buffered melt lens in the crust is related to the time it takes a magma body to cool $\left(t_{\text {cool }}\right)$ from its injection temperature to below the liquidus: $t_{\text {cool }}=V \rho C \Delta T / P$ where $V$ is the volume of the magma body, $\rho$ the magma density, $C$ the specific heat capacity, $T$ the temperature drop, and $P$ is the power output to the surrounding rocks. As an example (Fig. 8), $120 \mathrm{~km}^{3}$ of relatively dry, hot $\left(1300{ }^{\circ} \mathrm{C}\right)$ basalt, $\left(\rho=2800 \mathrm{~kg} / \mathrm{m}^{3} ; C=1390 \mathrm{~J} /\right.$ kg per K; $P=15 \mathrm{MW}$ ) immersed within a $\sim 1000{ }^{\circ} \mathrm{C}$ crustal mush zone as a $\sim 1 \mathrm{~km}$ thick sill that has a $6-7$ $\mathrm{km}$ radius would require $140 \mathrm{kyrs}$ to cool to a liquidus temperature of $1160{ }^{\circ} \mathrm{C}$.
In addition to the petrologic, isotopic, and thermal constraints on the plumbing system beneath Seguam [14,26-28], InSAR imagery was used to reconstruct surface deformation of the island from 1992 to 2000 [30,31]. The complex syn-and post-eruptive inflation and deflation pattern associated with the 1993 basalt eruption is best explained as a result of transient magma and vapor fluxes into and through a shallow ( $<7 \mathrm{~km}$ deep) plexus of dikes, driven from below by input of basaltic magma residing below $7 \mathrm{~km}$ [30]. Although the depth of the basaltic melt lens within the lower crust cannot be precisely determined from the InSAR data [30], it is likely to be perched between 12 and $15 \mathrm{~km}$ based on the interpretations of [14] and because it is thermodynamically less feasible at shallower depths. The proposed long-lived basaltic melt lens could be located at the base of the crust, where the temperature contrast between the magma chamber and

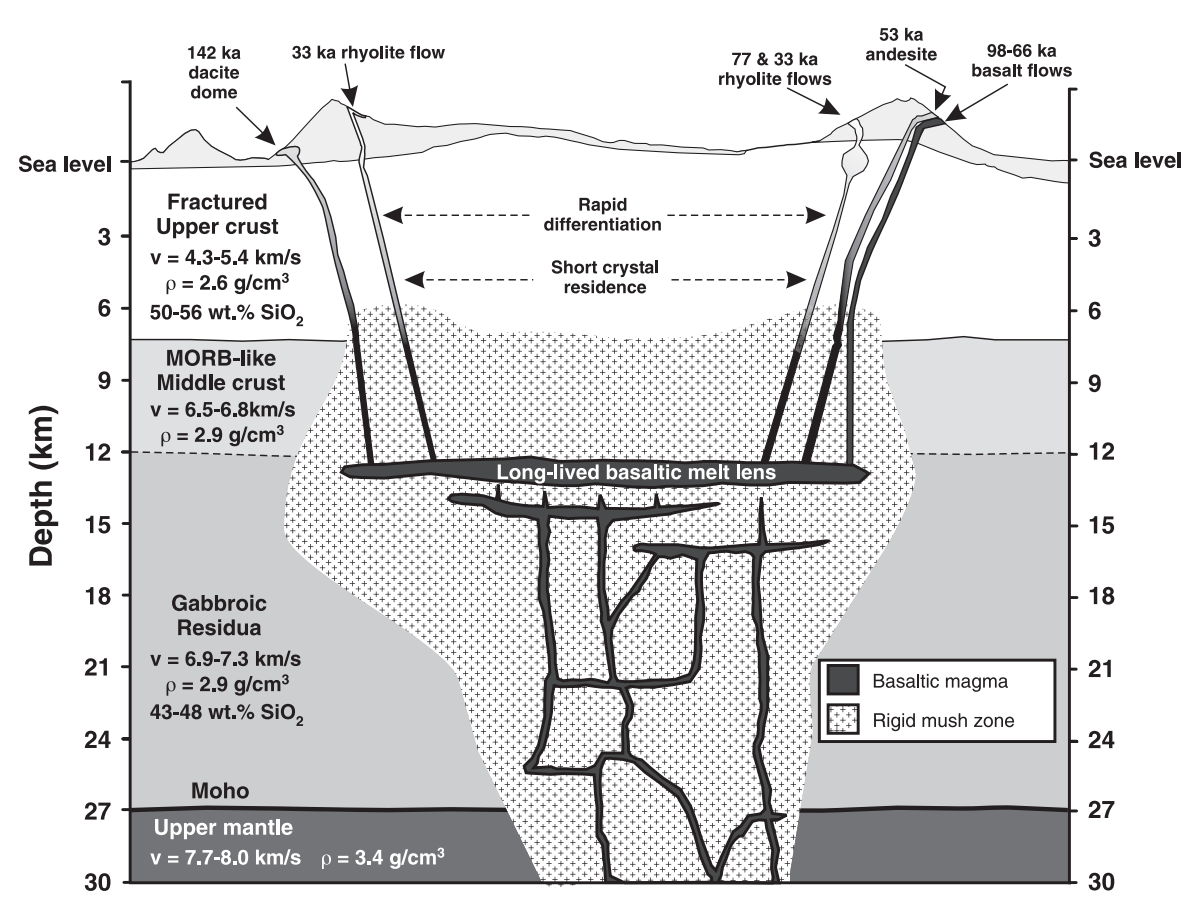

Fig. 8. Schematic southwest to northeast cross-section of the plumbing system beneath Seguam Island before caldera collapse at $\sim 9 \mathrm{ka}$. The bulk composition, thickness, and P-wave velocities of the subvolcanic crust are based on Holbrook et al. [34]. Crustal densities from [14]. Thermodynamic characteristics of the crustal mush zone and basaltic melt described in the text. Depth of the long-lived melt lens is constrained by InSAR and petrologic observations. Crystal fractionation to more evolved magma compositions is likely occurring rapidly in small chambers or conduits in the highly fractured upper crust. After caldera collapse, partial draining of the stagnant melt lens has likely allowed deeper magma to percolate upward throughout the mush column and some may be mixing with residual magma of the melt lens or directly feeding the postcaldera eruptions of basalt and rhyolite. 
the surrounding rocks would be much lower, but it is unlikely that the island wide inflation deduced from the InSAR imagery could be caused by a source that is 25 to $30 \mathrm{~km}$ below the surface (Fig. 8). Closed-system crystallization and differentiation of the basalt to andesite and rhyolite likely occurs in a nexus of shallow chambers or conduits in the upper crust as a response to rapid decompression, degassing and cooling of parental basalt $[14,36]$ (Fig. 8). The InSAR data suggest the presence of a $5 \mathrm{~km}^{3}$ storage region in the upper crust under the eastern half of the island, which may be where the dacitic ignimbrite-forming magma associated with stratocone collapse and the younger rhyolites were stored briefly prior to eruption. Finally, we would like to note that the U-series results by themselves, do not imply rapid differentiation of magma following isolated storage as melt for tens of kyrs. However, our model suggests that once a batch of magma becomes separated from the melt lens and crystal mush zone, it should begin to cool rapidly and differentiate because it is no longer thermally buffered.

\section{Conclusions}

U-Th isotope data from minerals, glass, and wholerocks, interpreted in light of ${ }^{40} \mathrm{Ar} /{ }^{39} \mathrm{Ar}$ ages, geochemical variations and $\mathrm{Sr}$ isotope compositions, indicate that phenocryst assemblages crystallized shortly, ca. $10^{3} \mathrm{yrs}$, before the eruption of a variety of basaltic to rhyolitic lavas and tuffs during the past $142 \mathrm{ka}$ at Seguam. We infer that this mainly reflects decompression-driven crystallization and differentiation as magmas ascended through the upper crust. Volcano collapse and eruption of a dacitic ignimbrite culminated a $130 \mathrm{kyr}$ period during which the $\left({ }^{230} \mathrm{Th} /{ }^{232} \mathrm{Th}\right)_{0}$ ratios of successively erupted magmas increased in a manner consistent with ${ }^{230} \mathrm{Th}$ ingrowth and while ${ }^{87} \mathrm{Sr} /{ }^{86} \mathrm{Sr}$ remained constant in an otherwise undisturbed magma reservoir. Suppression of crystallization for $10^{5}$ years implies minimal heat loss, suggesting either storage in hot wall rocks [39], or heating from deeper magma ponded below, but not in contact with, the stagnant melt. The $\left({ }^{230} \mathrm{Th} /{ }^{232} \mathrm{Th}\right)_{0}$ and ${ }^{87} \mathrm{Sr} /{ }^{86} \mathrm{Sr}$ ratios dropped abruptly in the ignimbrite at $9 \mathrm{ka}$ and in subsequent eruptions signaling the ascent of basaltic magma from a source different from that which fed magmas erupted over the preceding 130 kyrs.
A $>100$ kyr period of magma storage is at odds with the widely held view that magma residence times in island arcs are short $\left(\sim 10^{3}\right.$ years $)$ and that most variation in the transit time between partial melting and eruption originates in the mantle wedge $[2-4,18]$. The evidence for rapid ascent rates comes mainly from the U-Th-Ra series disequilibria in historical lavas erupted over the brief period encompassing the last few millennia [[1] and references therein, $[2,3,10,18,32,33]]$. Not all arc lavas exhibit significant ${ }^{226} \mathrm{Ra}$ excesses [42], thus although magma erupted recently at some volcanoes may have separated and ascended from its source over short time periods, the evidence for rapid ascent at other volcanoes is far less clear. The lone historical lava from Seguam that has been measured indicates a $12 \%$ excess of ${ }^{226} \mathrm{Ra}$ [32]. Thus, were we to have concentrated our investigation on only the most recent eruptions of the last $8 \mathrm{ka}$, as many U-Th-Ra studies have done, a far different conclusion that all magma ascent at Seguam was rapid may have been reached. Perhaps many of the eruptions in which excess ${ }^{226} \mathrm{Ra}$ have been found comprise magma that has indeed risen rapidly to replenish crustal reservoir systems as we have suggested for Seguam. Further work is needed to determine whether collapse of the stratocone and ignimbrite formation at $9 \mathrm{ka}$ reflects the influx and mixing of new ${ }^{230} \mathrm{Th}$ - and ${ }^{87} \mathrm{Sr}$ - poor basalt into the base of the long-lived melt lens, an often cited trigger for explosive eruptions [43], or if the eruption itself simply drained away the uppermost portion of the melt lens, permitting upward percolation of new basaltic melt from the mantle during the Holocene. Our results, alongside those from Irazu [6], should encourage further investigation of U-Th isotope disequilibrium at arc volcanoes over the $\sim 200 \mathrm{kyr}$ time period as a means of assessing magma ascent rates, storage times and the mechanisms that promote explosive eruptions.

\section{Acknowledgements}

We thank R.L. Edwards for sharing his knowledge of $U$ and Th chemical separation procedures, Captain Kevin Bell and the crew of the U.S. Fish and Wildlife Service M/V Tiglax for support of our sampling campaigns, Lee Powell and Xifan Zhang for his assistance 
in the Rare Gas Laboratory, and staff at the Oregon State University Radiation Center for the neutrons. Thorough and constructive reviews by Mary Reid and Michel Condomines are greatly appreciated. O. Sigmarsson graciously provided the AThO rock standard used in this project. Work supported by U.S. NSF grants EAR-0114055 and -0337667 and a Geological Society of America grant to BRJ.

\section{Appendix A. Supplementary data}

Supplementary data associated with this article can be found in the online version.

\section{References}

[1] M. Condomines, P.-J. Gauthier, O. Sigmarsson, Timescales of magma chamber processes and dating of young volcanic rocks, in: B. Bourdon, G.M. Henderson, C.C. Lundstrom, S.P. Turner (Eds.), Uranium Series Geochemistry, Reviews in Mineralogy and Geochemistry, The Mineralogical Society of America, Washington, DC, 2003, pp. 125-174.

[2] S.P. Turner, P. Evans, C. Hawkesworth, Ultrafast source-tosurface movement of melt at island arcs from ${ }^{226} \mathrm{Ra}-{ }^{230} \mathrm{Th}$ systematics, Science 292 (2001) 1363-1366.

[3] S. Turner, B. Bourdon, C. Hawkesworth, P. Evans, ${ }^{226} \mathrm{Ra}^{230} \mathrm{Th}$ evidence for multiple dehydration events, rapid melt ascent and the timescales of differentiation beneath the Tonga-Kermadec island arc, Earth Planet. Sci. Lett. 179 (2000) 581-593.

[4] S.P. Turner, R.M.M. George, P.J. Evans, C.J. Hawkesworth, G.F. Zellmer, Timescales of magma formation, ascent and storage beneath subduction-zone volcanoes, Philos. Trans. R. Soc. Lond. 358 (2000) 1443-1464.

[5] M.K. Reagan, K.W.W. Sims, J. Erich, R.B. Thomas, H. Cheng, R.L. Edwards, G. Layne, L. Ball, Time-scales of differentiation from mafic parents to rhyolite in North American continental arcs, J. Petrol. 44 (2003) 1703-1726.

[6] C.J. Allegre, M. Condomines, Fine chronology of volcanic processes using ${ }^{238} \mathrm{U}^{230} \mathrm{Th}$ systematics, Earth Planet. Sci. Lett. 28 (1976) 395-406.

[7] K.V. Cashman, B.D. Marsh, Crystal size distribution (CSD) in rocks and kinetics and dynamics of crystallization 2. Makaopuhi lava lake, Contrib. Mineral. Petrol. 99 (1988) 292-305.

[8] F. Costa, S. Chakraborty, R. Dohmen, Diffusion coupling between trace major elements and a model for calculation of magma residence times using plagioclase, Geochim. Cosmochim. Acta 67 (2003) 2189-2200.

[9] D.J. Morgan, S. Blake, N.W. Rogers, B. DeVivo, G. Rolandi, R. MacDonald, C.J. Hawkesworth, Timescales of crystal residence and magma chamber volume from modeling of diffu- sion profiles in phenocrysts: Vesuvius 1944, Earth Planet. Sci. Lett. 222 (2004) 933-946.

[10] G.F. Zellmer, S. Blake, D. Vance, C. Hawkesworth, S. Turner, Plagioclase residence times at two island arc volcanoes (Kameni Islands, Santorini, and Soufriere, St. Vincent) determined by $\mathrm{Sr}$ diffusion systematics, Contrib. Mineral. Petrol. 136 (1999) 345-357.

[11] C.J. Hawkesworth, S. Blake, P. Evans, R. Hughes, R. Macdonald, L. Thomas, S. Turner, G. Zellmer, Time scales of crystal fractionation in magma chambers-integrating physical, isotopic, and geochemical perspectives, J. Petrol. 41 (2000) 991-1006.

[12] W. Hildreth, M.A. Lanphere, Potassium-Argon geochronology of a basalt-andesite-dacite arc system - the Mount Adams volcanic field, Cascade Range of Southern Washington, Geol. Soc. Amer. Bull. 106 (1994) 1413-1429.

[13] B.S. Singer, R.A. Thompson, M.A. Dungan, T.C. Feeley, S.T. Nelson, J.C. Pickens, L.L. Brown, A.W. Wulff, J.P. Davidson, J. Metzger, Volcanism and erosion during the past $930 \mathrm{ky}$ at the Tatara-San Pedro complex, Chilean Andes, Geol. Soc. Amer. Bull. 109 (1997) 127-142.

[14] B.S. Singer, J.D. Myers, C.D. Frost, Mid-Pleistocene lavas from the Seguam volcanic center, central Aleutian arc: closedsystem fractional crystallization of a basalt to rhyodacite eruptive suite, Contrib. Mineral. Petrol. 110 (1992) 87-112.

[15] M. Condomines, J.C. Tanguy, G. Kieffer, C.J. Allegre, Magmatic evolution of a volcano studied by ${ }^{230} \mathrm{Th}-{ }^{238} \mathrm{U}$ disequilibrium and trace elements systematics: the Etna case, Geochim. Cosmochim. Acta 46 (1982) 1397-1416.

[16] S. Newman, R.C. Finkel, J.D. McDougall, Comparison of ${ }^{230} \mathrm{Th}-{ }^{238} \mathrm{U}$ disequilibrium systematics in lavas from three hot spot regions: Hawaii, Prince Edward and Samoa, Geochim. Cosmochim. Acta 48 (1984) 315-324.

[17] M. Condomines, C. Hemond, C. Allegre, U-Th-Ra radioactive disequilibria magmatic processes, Earth Planet Sci. Lett. 90 (1988) 243-262.

[18] G. Zellmer, S.P. Turner, C. Hawkesworth, Timescales of destructive plate margin magmatism: new insights from Santorini, Aegean volcanic arc, Earth Planet. Sci. Lett. 174 (2000) $265-281$.

[19] E. Heath, S.P. Turner, R. MacDonald, C.J. Hawkesworth, P. van Calsteren, Long magma residence times at an island arc volcano (Soufriere, St. Vincent) in the Lesser Antilles: evidence from ${ }^{238} \mathrm{U}-{ }^{230} \mathrm{Th}$ isochron dating, Earth Planet. Sci. Lett. 160 (1998) 49-63.

[20] S. Turner, R. George, D.A. Jerram, N. Carpenter, C. Hawkesworth, Case studies of plagioclase growth and residence times in island arc lavas from Tonga and the Lesser Antilles, and a model to reconcile discordant age information, Earth Planet. Sci. Lett. 214 (2003) 279-294.

[21] M.D. Feineman, D.J. DePaolo, Steady-state ${ }^{226} \mathrm{Ra} /{ }^{230} \mathrm{Th}$ disequilibrium in mantle minerals: implications for melt transport rates in island arcs, Earth Planet. Sci. Lett. 215 (2003) 339-355.

[22] R. George, M. Reagan, S. Turner, J. Gill, B. Bourdon, Comment on "Steady-state ${ }^{226} \mathrm{Ra} /{ }^{230} \mathrm{Th}$ disequilibrium in mantle minerals: implications for melt transport rates in island arcs", in: M.D. Feineman, D.J. DePaolo (Eds.), Earth Planet. Sci. Lett., vol. 228, 2005, pp. 563-567. 
[23] M.D. Feineman, D.J. DePaolo, Reply to Comment on "Steadystate ${ }^{226} \mathrm{Ra} /{ }^{230} \mathrm{Th}$ disequilibrium in mantle minerals: implications for melt transport rates in island arcs", in: R. George, M. Reagan, S. Turner, J. Gill, B. Bourdon (Eds.), Earth Planet. Sci. Lett., vol. 228, 2005, pp. 569-572.

[24] S.J. Goldstein, C.H. Stirling, Techniques for measuring uranium-series nuclides: 1992-2002, in: B. Bourdon, G.M. Henderson, C.C. Lundstrom, S.P. Turner (Eds.), Uranium-Series Geochemistry, M.S.A. and Geochemical Society, Washington, D.C., 2003, pp. $23-57$.

[25] H. Guillou, B.S. Singer, C. Laj, C. Kissel, S. Scaillet, B.R. Jicha, On the age of the Laschamp geomagnetic excursion, Earth Planet. Sci. Lett. 227 (2004) 331-343.

[26] B.R. Jicha, B.S. Singer, J.G. Brophy, J.H. Fournelle, C.M. Johnson, B.L. Beard, T.J. Lapen, N.J. Mahlen, Variable impact of the subducted slab on Aleutian Island arc magma sources: evidence from $\mathrm{Sr}, \mathrm{Nd}, \mathrm{Pb}$, and $\mathrm{Hf}$ isotopes and trace element abundances, J. Petrol. 45 (2004) 1845-1875.

[27] B.S. Singer, J.D. Myers, C.D. Frost, Mid-Pleistocene Basalt from the Seguam volcanic center, central Aleutian arc, Alaska: local lithospheric structures and source variability in the Aleutian arc, J. Geophys. Res. 97 (1992) 4561-4578.

[28] B.S. Singer, J.R. O'Neil, J.G. Brophy, Oxygen isotope constraints on the petrogenesis of Aleutian arc magmas, Geology 20 (1992) 367-370

[29] B.R. Jicha, B.S. Singer, Pleistocene-Recent growth and collapse of an island arc volcano: precise ${ }^{40} \mathrm{Ar} /{ }^{39} \mathrm{Ar}$ dating of Seguam Island, Central Aleutian arc, Alaska, EOS Trans. AGU 84 (2003) F1483.

[30] T. Masterlark, Z. Lu, Transient volcano deformation sources imaged with interferometric synthetic aperture radar: application to Seguam Island, Alaska, J. Geophys. Res. 109 (2004), doi:10.1029/2003JB002568.

[31] E. Price, Dynamic deformation of Seguam Island, Aleutians, Alaska, 1993-2000: implications for magmatic and hydrothermal processes, J. Geophys. Res. 109 (2004), doi:10.1029/ 2003JB002671.

[32] R. George, S. Turner, C. Hawkesworth, J. Morris, C. Nye, J. Ryan, S. Zheng, Melting processes and fluid and sediment transport rates along the Alaska-Aleutian arc from an integrated U-Th-Ra-Be isotope study, J. Geophys. Res. 108 (2003), doi:10.1029/2002JB001916.

[33] R. George, S. Turner, C. Hawkesworth, C.R. Bacon, C. Nye, P. Stelling, S. Dreher, Chemical versus temporal control on the evolution of tholeiitic and calc-alkaline magmas at two volcanoes in the Alaska-Aleutian arc, J. Petrol. 45 (2004) 203-219.

[34] W.S. Holbrook, D. Lizarralde, S. McGeary, N. Bangs, J. Diebold, Structure and composition of the Aleutian island arc and implications for continental crust growth, Geology 27 (1997) 31-34.

[35] Y. Asmerom, R.L. Edwards, U-series isotope evidence for the origin of continental basalts, Earth Planet. Sci. Lett. 134 (1995) $1-7$.

[36] J.G. Brophy, C.S. Whittington, Y.R. Park, Sector-zoned augite megacrysts in Aleutian high alumina basalts: implications for the conditions of basalt crystallization and the generation of calc-alkaline series magmas, Contrib. Mineral. Petrol. 135 (1999) 277-290.

[37] D.M. Pyle, M. Ivanovich, R.S.J. Sparks, Magma-cumulate mixing identified by $\mathrm{U}-\mathrm{Th}$ disequilibrium dating, Nature 331 (1988) 157-159.

[38] J. Blundy, B. Wood, Mineral-melt partition coefficients of uranium, thorium, and their daughters, in: B. Bourdon, G.M. Henderson, C.C. Lundstrom, S.P. Turner (Eds.), Uranium Series Geochemistry, Reviews in Mineralogy and Geochemistry, The Mineralogical Society of America, Washington, DC, 2003, pp. 59-123.

[39] C. Annen, R.S.J. Sparks, Effects of repetitive emplacement of basaltic intrusions on thermal evolution and melt generation in the crust, Earth Planet. Sci. Lett. 203 (2002) 937-955.

[40] O. Sigmarsson, M. Condomines, J.D. Morris, R.S. Harmon, Uranium and ${ }^{10} \mathrm{Be}$ enrichments by fluids in Andean arc magmas, Nature 346 (1990) 163-165.

[41] B.S. Singer, W.P. Leeman, M.F. Thirlwall, N.W. Rogers, Does fracture zone subduction increase sediment flux and mantle melting in subduction zones? Trace element evidence from Aleutian arc basalt, in: G.E. Bebout, D.W. Scholl, S.H. Kirby, J. Platt (Eds.), Subduction Top to Bottom, American Geophysical Union Monograph, vol. 96, 1996, pp. 285-291.

[42] S.P. Turner, B. Bourdon, J. Gill, Insights into magma genesis at convergent margins from U-series isotopes, in: B. Bourdon, G.M. Henderson, C.C. Lundstrom, S.P. Turner (Eds.), Uranium Series Geochemistry, Reviews in Mineralogy and Geochemistry, The Mineralogical Society of America, Washington, DC, 2003, pp. 255-315.

[43] J.S. Pallister, R.P. Hoblitt, R.A.G. Reyes, A basalt trigger for the 1991 eruptions of Pinatubo Volcano? Nature 356 (1992) $426-428$. 